\title{
Study of chemical changes and antioxidant activity variation induced by gamma-irradiation on wild mushrooms: comparative study through principal component analysis
}

\author{
Ângela Fernandes ${ }^{\mathrm{a}, \mathrm{b}}$, João C.M. Barreira ${ }^{\mathrm{a}, \mathrm{b}}$, Amilcar L. Antonio ${ }^{\mathrm{a}, \mathrm{c}, \mathrm{d}}$, Pedro M.P. Santos ${ }^{\mathrm{c}}$, \\ Anabela Martins $^{\mathrm{a}}$, M. Beatriz P.P. Oliveira ${ }^{\mathrm{b}}$, Isabel C.F.R. Ferreira ${ }^{\mathrm{a}}{ }^{*}$
}

${ }^{a}$ Centro de Investigação de Montanha, ESA, Instituto Politécnico de Bragança, Campus de Santa Apolónia, Apartado 1172, 5301-855 Bragança, Portugal.

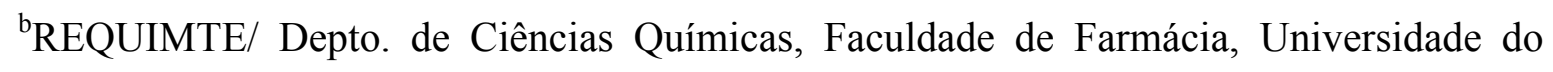
Porto, Rua Jorge Viterbo Ferreira n. ${ }^{\text {2 } 228, ~ 4050-313 ~ P o r t o, ~ P o r t u g a l . ~}$

'IST/ITN, Instituto Superior Técnico, Estrada Nacional 10, 2686-953 Sacavém, Portugal.

${ }^{\mathrm{d}}$ Departamento de Física Fundamental, Universidade de Salamanca, Plaza de la Merced, 37008 Salamanca, Spain.

\footnotetext{
*Author to whom correspondence should be addressed (I.C.F.R. Ferreira: iferreira@ipb.pt, tel. $+351-273303219$, fax $+351-273325405)$.
} 


\begin{abstract}
Mushrooms are especially sensitive to senescence, browning, water loss and microbial attack. Furthermore, wild species are characterized for their seasonality, demanding the development of suitable preservation technology. Gamma-irradiation was previously tested in wild Lactarius deliciosus, being verified that its application up to $1 \mathrm{kGy}$ did not imply significant changes in chemical parameters. Herein, the effects of higher gammairradiation doses, typically used in natural food matrices like fruits or vegetables, were assessed in Boletus edulis Bull.: Fr. and Hydnum repandum L.: Fr. by checking for changes in nutritional parameters, free sugars, tocopherols, fatty acids, organic acids and antioxidant activity indicators. To have representative samples, the used carpophores were collected in different maturity stages, using the same number of specimens for each stage and also for each mushroom species. The specific effects of each tested irradiation were evaluated in an integrated manner through principal component analysis. The correspondent biplots indicate that differences caused by gamma-irradiation are enough to separate irradiated and non-irradiated samples of both mushrooms. Nevertheless, nutritional profiles were not affected in high extension, indicating that gamma-irradiation, up to the doses used in this work, might represent a useful mushroom conservation technology.
\end{abstract}

Keywords: Wild mushrooms; Gamma irradiation; Chemical composition; Antioxidant activity; Principal component analysis 


\section{Introduction}

Mushrooms are highly perishable food matrices mainly due to the high water content (approx. 90\%), being easily deteriorated due to senescence, browning, water loss and microbial attack (Jolivet et al., 1998). Furthermore, wild mushrooms such as Boletus edulis Bull.:Fr. and Hydnum repandum L.:Fr. are strictly seasonal, causing difficulties in their distribution and marketing as fresh products; the level of loss in similar matrices during marketing could be as high as 40\% (Lacroix \& Ouattara, 2000). Therefore, mushrooms need special care to keep quality and freshness. The northeast of Portugal, due to its climatic conditions and flora diversity, is one of the European regions with a high variety of wild mushrooms, some of them with great gastronomic significance (Martins, Baptista, Sousa, Meireles, \& Pais, 2002). B. edulis and H. repandum are among the most commonly consumed wild mushrooms. Their popularity is mainly due to sensory qualities, in particular aroma, taste and texture. Moreover, it should be highlighted that wild species are considered add-value foods for commercialization in the markets of France and Spain (Martins et al., 2002).

Irradiation is recognized as a safe and effective method of preservation used worldwide to extend the shelf life of raw foods (e.g. fruits and vegetables, spices, grains, meat or seafood) (Andrews et al., 1998; Fernandes, Antonio, Oliveira, Martins, \& Ferreira, 2012a). In fact, more than 26 countries are using the process on a commercial scale (Stevenson, 1994; Lacroix \& Ouattara, 2000). Different cultivated mushrooms (mainly from Agaricus, Lentinula and Pleurotus genera) were previously studied using gamma-irradiation as a potential conservation technology (Fernandes et al., 2012a). Nevertheless, few studies were published regarding the application of gamma-irradiation in wild mushrooms. In a recent investigation studying the effects of gamma-irradiation on the chemical composition, antioxidant activity and physical parameters of fresh Lactarius deliciosus L. wild edible 
mushroom, we conclude that up to $1 \mathrm{kGy}$ this technology was effective in maintaining chemical composition and controlling the deterioration of fresh samples (Fernandes et al., 2012b; Fernandes et al., 2012c).

Herein, gamma-irradiation doses up to $2 \mathrm{kGy}$ were applied to B. edulis and H. repandum. In fact, a dose of $2.0 \mathrm{kGy}$ is usually the optimal dose that fruits and vegetables may tolerate to keep their quality intact (without suffering loss of firmness, change in flavor/taste, physiological breakage or accelerated ripening) (Lacroix \& Ouattara, 2000). In addition, the elimination of mold and pathogenic bacteria from mushrooms can be achieved with 2.0 $\mathrm{kGy}$ dose, increasing their shelf life from 2 to 8 days when stored at $10^{\circ} \mathrm{C}$ (Skou, Beett, \& Lundsten, 1974; Lacroix \& Ouattara, 2000). Accordingly, the effects on nutritional parameters, free sugars, tocopherols, fatty acids, organic acids and antioxidant activity were evaluated individually in each assayed mushroom. Furthermore, principal component analysis was applied to verify which specific parameters were more affected by each assayed gamma-irradiation dose.

\section{Materials and methods}

\subsection{Standards and reagents}

For irradiation: To estimate the dose and dose rate of irradiation it was used a chemical solution sensitive to ionizing radiation, Fricke dosimeter, prepared in the lab following the standards (ASTM, 1992) and Amber Perspex dosimeters (batch V, from Harwell Co., UK). To prepare the acid aqueous Fricke dosimeter solution the following reagents were used: ferrous ammonium sulfate(II) hexahydrate, sodium chloride and sulfuric acid, all purchased from Panreac S.A. (Barcelona, Spain) with purity PA (proanalysis), and water treated in a Milli-Q water purification system (Millipore, model A10, USA). 
For chemical analyses: Acetonitrile $99.9 \%$, n-hexane $95 \%$ and ethyl acetate $99.8 \%$ were of HPLC grade from Lab-Scan (Lisbon, Portugal). The fatty acids methyl ester (FAME) reference standard mixture 37 (standard 47885-U) was purchased from Sigma (St. Louis, MO, USA), as also other individual fatty acid isomers, organic acids, tocopherol and sugar standards. Racemic tocol, $50 \mathrm{mg} / \mathrm{mL}$, was purchased from Matreya (PA, USA).

For antioxidant potential analysis: 2,2-Diphenyl-1-picrylhydrazyl (DPPH) was obtained from Alfa Aesar (Ward Hill, MA, USA). Standards trolox (6-hydroxy-2,5,7,8tetramethylchroman-2-carboxylic acid) and gallic acid were from Sigma (St. Louis, MO, USA). Methanol and all other chemicals were of analytical grade and obtained from common sources. Water was treated in a Mili-Q water purification system (TGI Pure Water Systems, USA).

\subsection{Samples and samples irradiation}

B. edulis and H. repandum fruiting bodies (carpophores) were collected in different maturity stages; however, the same number of specimens belonging to each maturity stage was selected for both mushrooms. All mushrooms were collected in Trás-os-Montes (Northeast of Portugal) in November 2012.

B. edulis and $H$. repandum fresh samples were divided in three groups (each species) with three mushrooms per group. Each group corresponds to: control (non-irradiated, $0 \mathrm{kGy}$ ); sample 1 (1 kGy) and sample 2 (2 kGy).

The estimated dose rate for the irradiation position was obtained with Fricke dosimeter, and the irradiation of the samples was performed in a Co-60 experimental chamber with four sources, total activity $267 \mathrm{TBq}(6.35 \mathrm{kCi})$ in November 2011 (Precisa 22, Graviner Manufacturing Company Ltd, U.K.), following the procedure previously described by the authors (Fernandes et al., 2012c). The estimated doses, dose rates and dose uniformity 
ratios (Dmax/Dmin) were: 1.14 $\pm 0.23 \mathrm{kGy}, 1.71 \mathrm{kGy} / \mathrm{h}, 1.72$ and $1.99 \pm 0.32 \mathrm{kGy}, 1.49$ $\mathrm{kGy} / \mathrm{h}, 1.44$, for B. edulis; and 1.02 $\pm 0.04 \mathrm{kGy}, 1.53 \mathrm{kGy} / \mathrm{h}, 1.08$ and $1.66 \pm 0.46 \mathrm{kGy}, 1.24$ $\mathrm{kGy} / \mathrm{h}, 1.98, H$. repandum. For simplicity, in the text, tables and graphs we considered the values 0,1 and $2 \mathrm{kGy}$, for non-irradiated and irradiated samples of both mushroom species. All the samples were lyophilized (FreeZone 4.5 model 7750031, Labconco, Kansas, USA), reduced to a fine dried powder (20 mesh) and mixed to obtain homogenized samples for subsequent analysis.

\subsection{Chemical parameters}

2.3.1. Nutritional value. Moisture, protein, fat, carbohydrates and ash were determined following the AOAC procedures (AOAC, 1995). Moisture content was evaluated by lyophilization (FreeZone 4.5 model 7750031, Labconco, Kansas, USA), crude protein content $(N \times 4.38)$ of the samples was estimated by the macro-Kjeldahl method according to Léon-Guzmán et al. (1997); the crude fat was determined by extracting a known weight of powdered sample with petroleum ether, using a Soxhlet apparatus; the ash content was determined by incineration at $600 \pm 15{ }^{\circ} \mathrm{C}$ using a Chamber furnace Lenton Thermal Designs Ltd, model ECF 12/22. Total carbohydrates were calculated by difference. Energy was calculated according to the following equation: Energy $(\mathrm{kcal})=4 \times\left(\mathrm{g}_{\text {protein }}\right)+3.75 \times$ $\left(\mathrm{g}_{\text {carbohydrate }}\right)+9 \times\left(\mathrm{g}_{\mathrm{fat}}\right)$.

2.3.2. Free sugars. Free sugars were determined by high performance liquid chromatography coupled to a refraction index detector (HPLC-RI) after the extraction procedure described by Heleno et al. (2011), using melezitose as internal standard (IS). The equipment consisted of an integrated system with a pump (Knauer, Smartline system 1000), degasser system (Smartline manager 5000), auto-sampler (AS-2057 Jasco) and a RI 
detector (Knauer Smartline 2300). Data were analysed using Clarity 2.4 Software (DataApex). The chromatographic separation was achieved with a Eurospher 100-5 $\mathrm{NH}_{2}$ column $\left(4.6 \times 250 \mathrm{~mm}, 5 \mathrm{~mm}\right.$, Knauer) operating at $30{ }^{\circ} \mathrm{C}(7971 \mathrm{R}$ Grace oven $)$. The mobile phase was acetonitrile/deionized water, 70:30 (v/v) at a flow rate of $1 \mathrm{~mL} / \mathrm{min}$. The compounds were identified by chromatographic comparisons with authentic standards. Quantification was performed using the internal standard method and sugar contents were further expressed in $\mathrm{g}$ per $100 \mathrm{~g}$ of dry weight $(\mathrm{dw})$.

2.3.3. Fatty acids. Fatty acids were determined by gas-liquid chromatography with flame ionization detection (GC-FID), after the extraction and derivatization procedures described previously (Heleno et al., 2011). The analysis was carried out with a DANI model GC 1000 instrument equipped with a split/splitless injector, a FID at $260{ }^{\circ} \mathrm{C}$ and a MachereyNagel column 50\% cyanopropylmeythyl 50\% phenylmethylpolysiloxane $(30 \mathrm{~m} \times 0.32 \mathrm{~mm}$ ID $\times 0.25 \mu \mathrm{m} \mathrm{d} f$ ). The oven temperature program was as follows: the initial temperature of the column was $50^{\circ} \mathrm{C}$, held for $2 \mathrm{~min}$, then a $30^{\circ} \mathrm{C} / \mathrm{min}$ ramp to $125^{\circ} \mathrm{C}, 5^{\circ} \mathrm{C} / \mathrm{min}$ ramp to $160{ }^{\circ} \mathrm{C}, 20{ }^{\circ} \mathrm{C} / \mathrm{min}$ ramp to $180{ }^{\circ} \mathrm{C}, 3{ }^{\circ} \mathrm{C} / \mathrm{min}$ ramp to $200{ }^{\circ} \mathrm{C}, 20{ }^{\circ} \mathrm{C} / \mathrm{min}$ ramp to $220{ }^{\circ} \mathrm{C}$ and held for $15 \mathrm{~min}$. The carrier gas (hydrogen) flow-rate was $4.0 \mathrm{~mL} / \mathrm{min}(0.61 \mathrm{bar})$, measured at $50{ }^{\circ} \mathrm{C}$. Split injection $(1: 40)$ was carried out at $250{ }^{\circ} \mathrm{C}$. Fatty acid identification was made by comparing the relative retention times of FAME peaks from samples with standards. The results were recorded and processed using the CSW 1.7 Software (DataApex 1.7) and expressed in relative percentage of each fatty acid.

2.3.4. Tocopherols. Tocopherols were determined after an extraction procedure previously described, using tocol as IS (Heleno, Barros, Sousa, Martins, \& Ferreira, 2010). The analysis was carried out in the HPLC system described above connected to a fluorescence 
detector (FP-2020; Jasco) programmed for excitation at $290 \mathrm{~nm}$ and emission at $330 \mathrm{~nm}$. The chromatographic separation was achieved with a Polyamide II normal-phase column $\left(250 \times 4.6 \mathrm{~mm}\right.$; YMC Waters) operating at $30^{\circ} \mathrm{C}$. The mobile phase used was a mixture of n-hexane and ethyl acetate $(70: 30, \mathrm{v} / \mathrm{v})$ at a flow rate of $1 \mathrm{~mL} / \mathrm{min}$. The compounds were identified by chromatographic comparisons with authentic standards. Quantification was based on the fluorescence signal response, using the internal standard method, and tocopherols content was further expressed in mg per $100 \mathrm{~g}$ of dry weight (dw).

2.3.5. Organic acids. Organic acids were determined following a procedure previously optimized and described by the authors (Barros, Pereira, \& Ferreira, 2013). Analysis was performed by ultra fast liquid chromatograph (UFLC) coupled to photodiode array detector (PDA), using a Shimadzu 20A series UFLC (Shimadzu Cooperation). Detection was carried out in a PDA, using 215 and $245 \mathrm{~nm}$ as preferred wavelengths. The organic acids were quantified by comparison of the area of their peaks recorded at $215 \mathrm{~nm}$ with calibration curves obtained from commercial standards of each compound. The results were expressed in $\mathrm{mg}$ per $100 \mathrm{~g}$ of dry weight $(\mathrm{dw})$.

\subsection{Antioxidant parameters}

2.4.1. Extraction procedure. Lyophilized powdered mushrooms samples $(1 \mathrm{~g})$ were stirred with methanol $(30 \mathrm{~mL})$ at $25^{\circ} \mathrm{C}$ at $150 \mathrm{rpm}$ for $1 \mathrm{~h}$ and filtered through Whatman No. 4 paper. The residue was then extracted with an additional portion of methanol. The combined methanolic extracts were evaporated under reduced pressure (rotary evaporator Büchi R-210; Flawil, Switzerland), re-dissolved in methanol at $20 \mathrm{mg} / \mathrm{mL}$ (stock solution) for B. edulis and $40 \mathrm{mg} / \mathrm{mL}$ for $H$. repandum; and stored at $4^{\circ} \mathrm{C}$ for further use. Successive dilutions were made from the stock solution and submitted to in vitro assays already 
described by the authors (Heleno et al., 2010) to evaluate the antioxidant activity of the samples. The sample concentrations providing $50 \%$ of antioxidant activity or 0.5 of absorbance $\left(\mathrm{EC}_{50}\right)$ were calculated from the graphs of antioxidant activity percentages (DPPH, $\beta$-carotene/linoleate and TBARS assays) or absorbance at $690 \mathrm{~nm}$ (reducing power assay) against sample concentrations. Trolox was used as standard.

2.4.2. DPPH radical scavenging activity. This methodology was performed using an ELX800 Microplate Reader (Bio-Tek). The reaction mixture in each one of the 96-wells consisted of one of the different concentrations of the extracts $(30 \mu \mathrm{L})$ and methanolic solution $(270 \mu \mathrm{L})$ containing DPPH radicals $\left(6 \times 10^{-5} \mathrm{~mol} / \mathrm{L}\right)$. The mixture was left to stand for 60 min in the dark. The reduction of the DPPH radical was determined by measuring the absorption at $515 \mathrm{~nm}$. The radical scavenging activity (RSA) was calculated as a percentage of DPPH discoloration using the equation: $\% \mathrm{RSA}=\left[\left(\mathrm{A}_{\mathrm{DPPH}}-\mathrm{A}_{\mathrm{S}}\right) / \mathrm{A}_{\mathrm{DPPH}}\right]$ $\times 100$, where $A_{S}$ is the absorbance of the solution when the sample extract has been added at a particular level, and $\mathrm{A}_{\mathrm{DPPH}}$ is the absorbance of the DPPH solution.

2.4.3. Reducing power. Two different procedures were used to evaluate the reducing power:

A) The first methodology was performed using the Microplate Reader described above. The different concentrations of the extracts $(0.5 \mathrm{~mL})$ were mixed with sodium phosphate buffer $(200 \mathrm{mmol} / \mathrm{L}, \mathrm{pH} 6.6,0.5 \mathrm{~mL})$ and potassium ferricyanide $(1 \% \mathrm{w} / \mathrm{v}, 0.5 \mathrm{~mL})$. For each concentration, the mixture was incubated at $50{ }^{\circ} \mathrm{C}$ for $20 \mathrm{~min}$, and trichloroacetic acid $(10 \% \mathrm{w} / \mathrm{v}, 0.5 \mathrm{~mL})$ was added. The mixture $(0.8 \mathrm{~mL})$ was poured in the 48 -wells, as also deionized water $(0.8 \mathrm{~mL})$ and ferric chloride $(0.1 \% \mathrm{w} / \mathrm{v}, 0.16 \mathrm{~mL})$, and the absorbance was measured at $690 \mathrm{~nm}$. 
B) The second methodology followed the Folin-Ciocalteu assay. The extract solution (1 $\mathrm{mL}$ ) was mixed with Folin-Ciocalteu reagent $(5 \mathrm{~mL}$, previously diluted with water 1:10, $\mathrm{v} / \mathrm{v})$ and sodium carbonate $(75 \mathrm{~g} / \mathrm{L}, 4 \mathrm{~mL})$. The tubes were vortex mixed for $15 \mathrm{~s}$ and allowed to stand for $30 \mathrm{~min}$ at $40{ }^{\circ} \mathrm{C}$ for color development. Absorbance was then measured at $765 \mathrm{~nm}$. Gallic acid was used to obtain the standard curve (0.0094-0.15 $\mathrm{mg} / \mathrm{mL}$ ), and the results were expressed as $\mathrm{mg}$ of gallic acid equivalents (GAE) per $\mathrm{g}$ of extract.

2.4.4. Inhibition of $\beta$-carotene bleaching. $\beta$-carotene $(2 \mathrm{mg})$ was dissolved in chloroform $(10 \mathrm{~mL})$ and $2 \mathrm{~mL}$ of this solution were pipetted into a round-bottom flask. After the chloroform was removed at $40{ }^{\circ} \mathrm{C}$ under vacuum, linoleic acid (40 mg), Tween 80 emulsifier $(400 \mathrm{mg})$, and distilled water $(100 \mathrm{~mL})$ were added to the flask with vigorous shaking. Aliquots $(4.8 \mathrm{~mL})$ of this emulsion were transferred into different test tubes containing different concentrations of the extracts $(0.2 \mathrm{~mL})$. The tubes were shaken and incubated at $50{ }^{\circ} \mathrm{C}$ in a water bath. As soon as the emulsion was added to each tube, the zero time absorbance was measured at $470 \mathrm{~nm}$. $\beta$-Carotene bleaching inhibition was calculated using the following equation: (absorbance after $2 \mathrm{~h}$ of assay/initial absorbance) $\times 100$.

2.4.5. TBARS (thiobarbituric acid reactive substances) assay. Porcine (Sus scrofa) brains were obtained from official slaughtering animals, dissected, and homogenized with a Polytron in ice cold Tris- $\mathrm{HCl}$ buffer $(20 \mathrm{mM}, \mathrm{pH} 7.4)$ to produce a 1:2 w/v brain tissue homogenate which was centrifuged at $3000 \mathrm{~g}$ for $10 \mathrm{~min}$. An aliquot $(100 \mu \mathrm{L})$ of the supernatant was incubated with the different concentrations of the samples solutions (200 $\mu \mathrm{L})$ in the presence of $\mathrm{FeSO}_{4}(10 \mathrm{mM} ; 100 \mu \mathrm{L})$ and ascorbic acid $(0.1 \mathrm{mM} ; 100 \mu \mathrm{L})$ at 37 
${ }^{\circ} \mathrm{C}$ for $1 \mathrm{~h}$. The reaction was stopped by the addition of trichloroacetic acid $(28 \% \mathrm{w} / \mathrm{v}, 500$ $\mu \mathrm{L}$ ), followed by thiobarbituric acid (TBA, $2 \%$, w/v, $380 \mu \mathrm{L}$ ), and the mixture was then heated at $80{ }^{\circ} \mathrm{C}$ for $20 \mathrm{~min}$. After centrifugation at $3000 \mathrm{~g}$ for $10 \mathrm{~min}$ to remove the precipitated protein, the color intensity of the malondialdehyde (MDA)-TBA complex in the supernatant was measured by its absorbance at $532 \mathrm{~nm}$. The inhibition ratio (\%) was calculated using the following formula: Inhibition ratio $(\%)=[(\mathrm{A}-\mathrm{B}) / \mathrm{A}] \times 100 \%$, where A and B were the absorbance of the control and the sample solution, respectively.

\subsection{Statistical analysis}

All analyses (extractions) were performed in triplicate; each replicate was quantified also three times. Data were expressed as means \pm standard deviations.

The fulfillment of the one-way ANOVA requirements, specifically the normal distribution of the residuals and the homogeneity of variance, was tested by means of the ShapiroWilk's, and the Levene's tests, respectively. For each parameter, significant differences among mean values were checked by Welch's statistics $(p<0.05$ means that the mean value of the evaluated parameter of at least one irradiation differs from the others). In the cases where statistical significance differences were identified, the dependent variables were compared using Tukey's honestly significant difference (HSD) or Tamhane's T2 multiple comparison tests, when homoscedasticity was verified or not, respectively.

Principal components analysis (PCA) was applied as pattern recognition unsupervised classification method. PCA transforms the original, measured variables into new uncorrelated variables called principal components. The first principal component covers as much of the variation in the data as possible. The second principal component is orthogonal to the first and covers as much of the remaining variation as possible, and so on (Patras et al., 2011). The number of dimensions to keep for data analysis was evaluated by 
the respective eigenvalues (which should be greater than one), by the Cronbach's alpha parameter (that must be positive) and also by the total percentage of variance (that should be as higher as possible) explained by the number of components selected. The number of dimensions considered for PCA was chosen in order to allow meaningful interpretations, to ensure their reliability.

All statistical tests were performed at a 5\% significance level using the SPSS software, version 18.0 (SPSS Inc).

\section{Results and discussion}

Results regarding the evaluated chemical parameters and antioxidant activity assays are presented in Tables 1-6.

Nutritionally (Table 1), B. edulis and H. repandum showed similar profiles, presenting water as predominant component $(\approx 93 \%$ in $B$. edulis; $\approx 95 \%$ in $H$. repandum $)$ and carbohydrates $(\approx 70 \%$ in $B$. edulis; $\approx 75 \%$ in $H$. repandum $)$ as major compounds in dry mass basis, in agreement with previous works (Ouzouni \& Riganakos, 2007; Heleno et al. 2011). Fat contents were very low, highlighting the dietary interest of both species, especially in view of their low dry mass contents. Concerning the effects of gamma-irradiation, the most noticeable change was observed in protein content, which decreased with irradiation for both mushrooms. Actually, proteins are among the most reliable irradiation indicators, especially due to degradation reactions such as scission of the $\mathrm{C}-\mathrm{N}$ bonds in the backbone of the polypeptide chain or splitting of the dissulfide bonds, and physical changes like unfolding and aggregation (Molins, 2001). The remaining nutritional parameters showed very slight changes in response to the applied gamma-irradiation doses; dry mass, in particular did not reveal significant ( $p=0.775$ for $B$. edulis; $p=0.156$ for $H$. repandum) variation among irradiated and non-irradiated samples. 
Free sugars profiles (Table 2) were quite different among the assayed species: trehalose was the main $(\approx 14 \mathrm{~g} / 100 \mathrm{~g} \mathrm{dw})$ sugar in B. edulis, a value similar to the previously reported by our research group (Heleno et al., 2011), while mannitol predominated $(\approx 14$ $\mathrm{g} / 100 \mathrm{~g} \mathrm{dw}$ ) in $H$. repandum. The identified sugars decreased with irradiation in all cases. Sugars are known as being good indicators of a suitable conservation technology due to their sensibility to technical practices (Barreira, Pereira, Oliveira, \& Ferreira, 2010). Irradiation, in particular, is known for causing several changes in sugars, such as melting point decreases, reduction in optical rotation and browning. Furthermore, sugars may suffer degradation, producing a mixture of gases consisting primarily of $\mathrm{H}_{2}$ and $\mathrm{CO}_{2}$, together with traces of $\mathrm{CH}_{4}, \mathrm{CO}$ and $\mathrm{H}_{2} \mathrm{O}$. The relative proportions depends on the type of sugar irradiated and the absorbed dose (Molins, 2001), as verified in this case, where 1 kGy caused the minimization of sugar contents.

Tocopherol contents (Table 3) suffered the most marked effect in all quantified isoforms $(\alpha-, \gamma$ - and $\delta$-tocopherol) presenting maximum values in samples irradiated with $1 \mathrm{kGy}$. Interestingly, the same irradiation dose minimized free sugars and maximized $\gamma$ - and $\delta$ tocopherol, a result that might be explained by the packaging atmosphere changes as a result of sugars degradation, since degradation of tocopherols is highly related with the availiability of free oxygen. $\alpha$-Tocopherol, present in low amounts, was only detected in non-irradiated samples.

In what regards fatty acids (FA), 25 individual molecules were quantified in both mushroom species. Table 4 presents the individual FA quantified above $0.2 \%$ in each mushroom species (C8:0, C10:0, C12:0, C14:1, C15:0, C17:0, C18:3, C20:3, C20:5, C22:1, C23:0 and C24:1 in both mushrooms, besides C6:0, C17:1 and C22.0 in B. edulis and $\mathrm{C} 14: 0$ in $H$. repandum were also quantified, but in percentages lower than $0.2 \%$ ). The most abundant FA in both mushrooms were palmitic acid (C16:0), oleic acid (C18:1) and 
linoleic acid (C18:2), as it is common in these species (Kalač, 2009; Heleno et al., 2011). The high percentage of the latter should probably be associated with the highly appreciated organoleptic characteristics of these mushrooms, since linoleic acid is the precursor of oct1-en-3-ol, known as "fungi alcohol", the main aromatic component in fungi (Maga, 1981). It became evident that irradiation cause a decrease in unsaturated fatty acids. Irradiation may change lipid profile by catalyzing their reaction with molecular oxygen (autoxidation) or by the action of high-energy radiation itself, more evidently in both cases in unsaturated molecules (Nawar, 1986). In fact, the general mechanism of lipids radiolysis is thought to involve primary ionization, followed by migration of the positive charge either toward the carboxyl carbonyl group or double bonds (Molins, 2001), thus enhancing unsaturated fatty acids degradation.

The profiles in organic acids (Table 5) were different among the two assayed mushrooms, particularly in what regards malic acid, which was absent in B. edulis. However, citric acid was the predominant organic acid, except in $H$. repandum samples irradiated with $2 \mathrm{kGy}$. Irradiated samples (excluding oxalic acid in B. edulis) presented higher organic acids values, as it was previously verified for tocopherols.

The antioxidant potential of $B$. edulis and $H$. repandum was used as a measure of their bioactivity. Five in vitro chemical and biochemical assays were used: scavenging effects on DPPH radicals (measures the decrease in DPPH radical absorption after exposure to radical scavengers), reducing power (conversion of a $\mathrm{Fe}^{3+} /$ ferricyanide complex to $\mathrm{Fe}^{2+}$, further denominated as Prussian blue assay, and Folin-Ciocalteau method), inhibition of $\beta$ carotene bleaching (measures the capacity to neutralize the linoleate-free radical and other free radicals formed in the system which attack the highly unsaturated $\beta$-carotene models) and inhibition of lipid peroxidation in brain cells homogenates (measures the color intensity of MDA-TBA complex formed at the endpoint of the reaction). As mentioned in 
previous reports, B. edulis also gave higher antioxidant activity than $H$. repandum (Heleno et al., 2010; Heleno et al., 2011). Performed assays (Table 6) indicate that irradiated samples tended to have lower scavenging activity and reducing power, but higher lipid peroxidation inhibition. The observed decrease might be related with free radicals resulting from lipid radiolysis, which was higher in irradiated samples. On the other hand, the increase in lipid peroxidation inhibition is probably associated to the higher amount of tocopherols (powerful lipophilic antioxidants) detected in irradiated samples.

To verify which parameters were more related with the detected differences, a principal components analysis (PCA) was applied to each mushroom species. The plot of component loadings (Figure 1) for B. edulis, indicates that the first two dimensions (first: Cronbach's $\alpha, 0.980$; eigenvalue, 24.793; second: Cronbach's $\alpha, 0.962$; eigenvalue, 17.447) account for most of the variance of all quantified variables (50.60\% and $35.61 \%$, respectively). Groups corresponding to each irradiation level ( $0 \mathrm{kGy}, 1 \mathrm{kGy}$ and $2 \mathrm{kGy})$ were clearly separated. Group corresponding to $0 \mathrm{kGy}$ was more positively correlated to proteins, $\alpha$-tocopherol, C6:0, C18:2, PUFA and TBARS (i.e., it presented high contents in these parameters and was a weak inhibitor of TBARS formation); and more negatively correlated to fat, carbohydrates, C15:0, C17:1, C18:1, $\beta$-carotene and DPPH (i.e., it presented low contents in these parameters and was a strong DPPH scavenger). $1 \mathrm{kGy}$ was more positively correlated to ash, C23:0, C24:0, MUFA, fumaric acid and reducing power (Prussian blue assay, PBA); the highest negative correlations were associated to energy, fructose, C20:0, C20:5 and reducing power (Folin-Ciocalteau assay, F-CA); it should be noted that the correlations with reducing power are not conflicting since high values in PBA and low values in FC-A both mean lower reducing power. Objects corresponding to $2 \mathrm{kGy}$ were 
mostly characterized by high contents in C10:0, C12:0, C14:0, C16:0, C17:0 and C20:3 and low contents in C20:2, C22:1, C24:1 and oxalic acid.

In what concerns $H$. repandum (Figure 2) objects corresponding to each irradiation level were also clearly separated. The first two dimensions (first: Cronbach's $\alpha, 0.986$; eigenvalue, 28.386; second: Cronbach's $\alpha, 0.907$; eigenvalue, 8.855) include also most of the variance of all quantified variables (61.71\% and $19.25 \%$, respectively). In this case, group corresponding to $0 \mathrm{kGy}$ was more positively correlated to fat, energy, mannitol, trehalose, $\alpha$-tocopherol, C18:2, C18:3, C20:1 and PUFA, and more negatively correlated to C6:0, C8:0, C14:1, C16:0, C17:0, C18:0, C18:1, C20:0, C22:0, C22:1, C24:0 and oxalic acid. Objects corresponding to $1 \mathrm{kGy}$ were more positively correlated to C24:1, MUFA, citric acid and reducing power (F-CA); no negative correlations were detected. Finally, 2 kGy group was mostly characterized by having high scores in carbohydrates, C10:0, $\mathrm{C} 12: 0, \mathrm{C} 14: 0, \mathrm{C} 15: 0, \mathrm{C} 16: 1$, fumaric acid, malic acid, $\beta$-carotene bleaching prevention, TBARS formation inhibition and reducing power (PBA) and low contents in dry matter, proteins, C20:2, C20:3 and C20:5.

Overall, it might be concluded that irradiation caused changes in minor individual compounds. The spatial distribution of PCA biplot markers in different clusters (corresponding to each irradiation dose) confirmed that irradiation exerted marked effects over the assayed parameters. Fatty acids in particular, seemed to be the most affected components, since their component loadings were often correlated with the defined objects. Nevertheless, despite the detected differences in individual compounds, the results of nutritional parameters (the most relevant in terms of mushroom acceptability by consumers) were less affected, indicating an interesting potential of gamma-irradiation to be used as an effective conservation technology. Furthermore, considering previous 
research outcomes, irradiation minimizes the effects caused by storage time, being definitely indicated to be applied to mushrooms.

\section{Acknowledgements}

Authors are grateful to the Foundation for Science and Technology (FCT, Portugal) for financial support to research centres CIMO (PEst-OE/AGR/UI0690/2011) and REQUIMTE (PEst-C/EQB/LA0006/2011). Â. Fernandes, J.C.M. Barreira and A.L. Antonio thank FCT, POPH-QREN and FSE for their grants (SFRH/BD/76019/2011, SFRH/BPD/72802/2010 and SFRH/PROTEC/67398/2010, respectively).

\section{References}

Andrews, L.S., Ahmedna, M., Grodner, R. M., Liuzzo, J.A., Murano, P.S., \& Murano, E. A. (1998). Food preservation using ionizing radiation. Review of Environmental and Contaminant Toxicology, 154, 1-53.

AOAC. (1995). Official methods of analysis (16 ${ }^{\text {th }}$ Ed.). Arlington VA, USA: Association of Official Analytical Chemists.

Barreira, J.C.M., Pereira, J.A., Oliveira, M.B.P.P., \& Ferreira, I.C.F.R. (2010). Sugars profiles of different chestnut (Castanea sativa Mill.) and almond (Prunus dulcis) Cultivars by HPLC-RI. Plant Foods for Human Nutrition, 65, 38-43.

Barros, L., Pereira, C., \& Ferreira, I.C.F.R. (2013). Optimized analysis of organic acids in edible mushrooms from Portugal by ultra fast liquid chromatography and photodiode array detection. Food Analytical Methods, 6, 309-316.

Fernandes, Â., Antonio, A. L., Barreira, J. C. M., Botelho, L., Oliveira, M. B. P. P., Martins, A., \& Ferreira, I. C. F. R. (2012c). Effects of gamma irradiation on the chemical composition and antioxidant activity of Lactarius deliciosus L. wild edible mushroom. Food and Bioprocess Technology, doi 10.1007/s11947-012-0931-5. 
Fernandes, Â., Antonio, A.L., Barreira, J.C.M., Oliveira, M.B.P.P., Martins, A., \& Ferreira, I.C.F.R. (2012b). Effects of gamma irradiation on physical parameters of Lactarius deliciosus wild edible mushroom. Postharvest Biology and Technology, $74,79-84$.

Fernandes, Â., Antonio, A.L., Oliveira, M.P.P., Martins, A., \& Ferreira, I.C.F.R. (2012a). Effect of gamma and electron beam irradiation on the physico-chemical and nutritional properties of mushrooms: A review. Food Chemistry, 135, 641-650.

Heleno, S.A., Barros, L., Sousa, M. J., Martins, A., \& Ferreira, I.C.F.R. (2010). Tocopherols composition of Portuguese wild mushrooms with antioxidant capacity. Food Chemistry, 119, 1443-1450.

Heleno, S.A., Barros, L., Sousa, M.J., Martins, A., Santos-Buelga, C., \& Ferreira, I.C.F.R. (2011). Targeted metabolites analysis in wild Boletus species. LWT-Food Science and Technology, 44, 1343-1348.

Jolivet, S., Arpin, N., Wichers, H.J., \& Pellon, G. (1998). Agaricus bisporus browning: a review. Mycological Research, 102, 1459-1483.

Kalač, P. (2009). Chemical composition and nutritional value of European species of wild growing mushrooms: A review. Food Chemistry, 113, 9-16.

Lacroix, M., \& Ouattara, B. (2000). Combined industrial processes with irradiation to assure innocuity and preservation of food products - a review. Food Research International, 33, 719-724.

Léon-Guzmán, M.F., Silva, I., \& Lopez, M.G. (1997). Proximate chemical composition, free amino acid contents, and free fatty acids contents of some wild edible mushrooms from Queretaro, Mexico. Journal of Agricultural and Food Chemistry, $45,4329-4332$.

Maga J.A. (1981). Mushroom flavor. Journal of Agricultural and Food Chemistry, 29, 4-7. 
Martins, A., Baptista, P., Sousa, M.J., Meireles, T., \& Pais, M.S. (2002). Edible mycorrhizal fungi associated with Castanea sativa Mill trees in the Northeast of Portugal. In I. Hall, Wan Yun, E. Danell, A. Zambonelli (Eds.). Proceedings of the second international workshop on edible mycorrhizal fungi. ISBN 0-478-10828-X.

Molins, R. (2001). Food Irradiation. Principles and applications. John Wiley \& Sons, USA. ISBN 0-471-35634-4.

Nawar, W.W. (1986). Volatiles from food irradiation. Food Reviews International, 2, 4578.

Ouzouni, P. K., \& Riganakos, K. A. (2007). Nutritional value and metal content of Greek wild edible fungi. Acta Alimentaria, 36, 99-110.

Patras, A., Brunton, N.P., Downey, G., Rawson, A., Warriner, K., \& Gernigon, G. (2011). Application of principal component and hierarchical cluster analysis to classify fruits and vegetables commonly consumed in Ireland based on in vitro antioxidant activity. Journal of Food Composition and Analysis, 24, 250-256.

Skou, J. F., Beett, H., \& Lundsten, K. (1974). E€ects of ionizing radiation on mushroms as influenced by physiological and environmental conditions. Radiation Botany, 14, 287-299.

Stevenson, M.H. (1994). Nutritional and other implications of irradiating meat. Proceedings of the Nutrition Society, 53, 317-325. 
Table 1. Proximate composition and corresponding energetic value of B. edulis and H. repandum samples submitted to different gamma irradiation doses. The results are presented as mean $\pm \mathrm{SD}^{a}$.

\begin{tabular}{|c|c|c|c|c|c|c|c|}
\hline & & $\begin{array}{l}\text { Dry matter } \\
(\mathrm{g} / 100 \mathrm{~g} \mathrm{fw})\end{array}$ & $\begin{array}{c}\text { Fat } \\
(\mathrm{g} / 100 \mathrm{~g} \mathrm{dw})\end{array}$ & $\begin{array}{c}\text { Proteins } \\
(\mathrm{g} / 100 \mathrm{~g} \mathrm{dw})\end{array}$ & $\begin{array}{c}\text { Carbohydrates } \\
(\mathrm{g} / 100 \mathrm{~g} \mathrm{dw})\end{array}$ & $\begin{array}{c}\text { Ash } \\
(\mathrm{g} / 100 \mathrm{~g} \mathrm{dw})\end{array}$ & $\begin{array}{c}\text { Energy } \\
\text { (kcal/100 g dw) }\end{array}$ \\
\hline \multirow{3}{*}{ Boletus edulis } & $0 \mathrm{kGy}$ & $7 \pm 1$ & $4.3 \pm 0.3 \mathrm{~b}$ & $23 \pm 2 \mathrm{a}$ & $65 \pm 2 \mathrm{~b}$ & $7.9 \pm 0.1 \mathrm{~b}$ & $390 \pm 2 \mathrm{ab}$ \\
\hline & 1 kGy & $7.3 \pm 0.4$ & $4.6 \pm 0.1 \mathrm{a}$ & $15 \pm 1 \mathrm{~b}$ & $72 \pm 1 \mathrm{a}$ & $8.6 \pm 0.2 \mathrm{a}$ & $389 \pm 1 \mathrm{~b}$ \\
\hline & $2 \mathrm{kGy}$ & $7 \pm 1$ & $4.5 \pm 0.1 \mathrm{ab}$ & $16.0 \pm 0.4 \mathrm{~b}$ & $71.5 \pm 0.5 \mathrm{a}$ & $7.9 \pm 0.2 \mathrm{~b}$ & $391 \pm 1 \mathrm{a}$ \\
\hline Homoscedasticity $^{b}$ & $p$-value & 0.004 & $<0.001$ & 0.001 & $<0.001$ & 0.003 & 0.022 \\
\hline \multirow[t]{2}{*}{ One-way ANOVA ${ }^{c}$} & $p$-value & 0.775 & 0.002 & $<0.001$ & $<0.001$ & $<0.001$ & 0.003 \\
\hline & $0 \mathrm{kGy}$ & $6 \pm 2$ & $4.6 \pm 0.1 \mathrm{a}$ & $14.1 \pm 0.2 \mathrm{a}$ & $72 \pm 1 \mathrm{~b}$ & $9 \pm 1 \mathrm{c}$ & $385 \pm 4 \mathrm{a}$ \\
\hline \multirow[t]{2}{*}{ Hydnum repandum } & $1 \mathrm{kGy}$ & $6 \pm 1$ & $4.0 \pm 0.2 \mathrm{~b}$ & $12.2 \pm 0.1 \mathrm{~b}$ & $72.7 \pm 0.3 b$ & $11.1 \pm 0.2 \mathrm{a}$ & $376 \pm 1 \mathrm{c}$ \\
\hline & $2 \mathrm{kGy}$ & $4.5 \pm 0.1$ & $4.0 \pm 0.1 \mathrm{~b}$ & $8 \pm 1 \mathrm{c}$ & $77 \pm 1 \mathrm{a}$ & $10.4 \pm 0.1 \mathrm{~b}$ & $378 \pm 1 \mathrm{~b}$ \\
\hline Homoscedasticity $^{b}$ & $p$-value & 0.001 & 0.894 & 0.003 & 0.051 & $<0.001$ & $<0.001$ \\
\hline One-way ANOVA ${ }^{c}$ & $p$-value & 0.156 & $<0.001$ & $<0.001$ & $<0.001$ & $<0.001$ & $<0.001$ \\
\hline
\end{tabular}

fw- fresh weight; dw- dry weight.

${ }^{a}$ Different letters in each column and for each mushroom indicate significant differences among mean values of each gamma irradiation level.

${ }^{b}$ Homoscedasticity among cultivars was tested by means of the Levene test: homoscedasticity, $p$-value $>0.05$; heteroscedasticity, $p$-value $<0.05$.

${ }^{c} p<0.05$ meaning that the mean value of the evaluated parameter of at least one irradiation differs from the others (in this case multiple comparison tests were

performed). 
Table 2. Sugars composition of B. edulis and H. repandum samples submitted to different gamma irradiation doses. The results are presented as mean $\pm \mathrm{SD}^{a}$.

\begin{tabular}{llccccc}
\hline & & $\begin{array}{c}\text { Fructose } \\
(\mathrm{g} / 100 \mathrm{~g} \mathrm{dw})\end{array}$ & $\begin{array}{c}\text { Glucose } \\
(\mathrm{g} / 100 \mathrm{~g} \mathrm{dw})\end{array}$ & $\begin{array}{c}\text { Mannitol } \\
(\mathrm{g} / 100 \mathrm{~g} \mathrm{dw})\end{array}$ & $\begin{array}{c}\text { Trehalose } \\
(\mathrm{g} / 100 \mathrm{~g} \mathrm{dw})\end{array}$ & $\begin{array}{c}\text { Total sugars } \\
(\mathrm{g} / 100 \mathrm{~g} \mathrm{dw})\end{array}$ \\
\hline \multirow{3}{*}{ Boletus edulis } & $0 \mathrm{kGy}$ & $0.41 \pm 0.01 \mathrm{~b}$ & $1.57 \pm 0.03 \mathrm{a}$ & $1.13 \pm 0.03 \mathrm{a}$ & $17.7 \pm 0.1 \mathrm{a}$ & $20.9 \pm 0.1 \mathrm{a}$ \\
& $1 \mathrm{kGy}$ & $0.21 \pm 0.02 \mathrm{c}$ & $0.80 \pm 0.02 \mathrm{c}$ & $0.32 \pm 0.02 \mathrm{c}$ & $11.3 \pm 0.1 \mathrm{c}$ & $12.6 \pm 0.1 \mathrm{c}$ \\
& $2 \mathrm{kGy}$ & $0.45 \pm 0.02 \mathrm{a}$ & $1.29 \pm 0.03 \mathrm{~b}$ & $0.67 \pm 0.01 \mathrm{~b}$ & $14.1 \pm 0.1 \mathrm{~b}$ & $16.5 \pm 0.1 \mathrm{~b}$ \\
\hline Homoscedasticity $^{b}$ & $p$-value & 0.080 & 0.424 & 0.016 & 0.067 & 0.036 \\
One-way ANOVA $^{c}$ & $p$-value & $<0.001$ & $<0.001$ & $<0.001$ & $<0.001$ & $<0.001$ \\
\hline \multirow{3}{*}{ Hydnum repandum } & $1 \mathrm{kGy}$ & $\mathrm{kg}$ & $\mathrm{nd}$ & $13.0 \pm 0.2 \mathrm{a}$ & $4.4 \pm 0.1 \mathrm{a}$ & $17.4 \pm 0.2 \mathrm{a}$ \\
& $2 \mathrm{kGy}$ & $\mathrm{nd}$ & $\mathrm{nd}$ & $12.5 \pm 0.1 \mathrm{~b}$ & $4.25 \pm 0.02 \mathrm{~b}$ & $16.8 \pm 0.1 \mathrm{~b}$ \\
& $p$-value & nd & nd & $12.6 \pm 0.1 \mathrm{~b}$ & $4.3 \pm 0.1 \mathrm{~b}$ & $16.9 \pm 0.1 \mathrm{~b}$ \\
\hline Homoscedasticity $^{b}$ & - & - & 0.007 & $<0.001$ & 0.209 \\
One-way ANOVA $^{c}$ & $p$-value & - & - & $<0.001$ & $<0.001$ & $<0.001$ \\
\hline
\end{tabular}

dw- dry weight; nd- not detected.

${ }^{a}$ Different letters in each column and for each mushroom indicate significant differences among mean values of each gamma irradiation level.

${ }^{b}$ Homoscedasticity among irradiation doses was tested by means of the Levene test: homoscedasticity, $p$-value $>0.05$; heteroscedasticity, $p$-value $<0.05$.

${ }^{c} p<0.05$ meaning that the mean value of the evaluated parameter of at least one irradiation differs from the others (in this case multiple comparison tests were performed). 
Table 3. Tocopherols composition of $B$. edulis and H. repandum samples submitted to different gamma irradiation doses. The results are presented as mean $\pm \mathrm{SD}^{a}$.

\begin{tabular}{|c|c|c|c|c|c|}
\hline & & $\begin{array}{l}\alpha \text {-Tocopherol } \\
(\mu \mathrm{g} / 100 \mathrm{~g} \mathrm{dw})\end{array}$ & $\begin{array}{l}\gamma \text {-Tocopherol } \\
(\mu \mathrm{g} / 100 \mathrm{~g} \mathrm{dw})\end{array}$ & $\begin{array}{l}\delta \text {-Tocopherol } \\
(\mu \mathrm{g} / 100 \mathrm{~g} \mathrm{dw})\end{array}$ & $\begin{array}{c}\text { Total tocopherols } \\
(\mu \mathrm{g} / 100 \mathrm{~g} \mathrm{dw})\end{array}$ \\
\hline \multirow{3}{*}{ Boletus edulis } & $0 \mathrm{kGy}$ & $1.5 \pm 0.1$ & $25 \pm 2 b$ & $33 \pm 4 \mathrm{~b}$ & $59 \pm 2 \mathrm{~b}$ \\
\hline & $1 \mathrm{kGy}$ & nd & $85 \pm 3 \mathrm{a}$ & $58 \pm 1 \mathrm{a}$ & $143 \pm 3 \mathrm{a}$ \\
\hline & $2 \mathrm{kGy}$ & nd & nd & $24 \pm 1 \mathrm{c}$ & $24 \pm 1 \mathrm{c}$ \\
\hline Homoscedasticity $^{b}$ & $p$-value & $<0.001$ & $<0.001$ & $<0.001$ & $<0.001$ \\
\hline One-way ANOVA ${ }^{c}$ & $p$-value & $<0.001$ & $<0.001$ & $<0.001$ & $<0.001$ \\
\hline \multirow{3}{*}{ Hydnum repandum } & $0 \mathrm{kGy}$ & $2.19 \pm 0.03$ & nd & $8.9 \pm 0.2 \mathrm{c}$ & $11.1 \pm 0.2 \mathrm{c}$ \\
\hline & $1 \mathrm{kGy}$ & nd & nd & $113 \pm 1 \mathrm{a}$ & $113 \pm 1 \mathrm{a}$ \\
\hline & $2 \mathrm{kGy}$ & nd & nd & $80 \pm 2 \mathrm{~b}$ & $80 \pm 1 \mathrm{~b}$ \\
\hline Homoscedasticity $^{b}$ & $p$-value & $<0.001$ & - & 0.007 & 0.045 \\
\hline One-way ANOVA ${ }^{c}$ & $p$-value & $<0.001$ & - & $<0.001$ & $<0.001$ \\
\hline
\end{tabular}

dw- dry weight; nd- not detected.

${ }^{a}$ Different letters in each column and for each mushroom indicate significant differences among mean values of each gamma irradiation level.

${ }^{b}$ Homoscedasticity among irradiation doses was tested by means of the Levene test: homoscedasticity, $p$-value $>0.05$; heteroscedasticity, $p$-value $<0.05$.

${ }^{c} p<0.05$ meaning that the mean value of the evaluated parameter of at least one irradiation dose differs from the others (in this case multiple comparison tests were performed) 
Table 4. Fatty acids composition (relative percentages) of B. edulis and H. repandum samples submitted to different gamma irradiation doses.

The results are presented as mean $\pm \mathrm{SD}^{a}$.

\begin{tabular}{|c|c|c|c|c|c|c|c|c|c|c|c|c|c|c|c|}
\hline & & C14:0 & C16:0 & C16:1 & C18:0 & C18:1 & C18:2 & C20:0 & $\mathrm{C} 20: 1$ & C20:2 & $\mathrm{C} 24: 0$ & SFA & MUFA & PUFA & \\
\hline \multirow{3}{*}{ Boletus edulis } & 0 kGy & $0.100 \pm 0.002 \mathrm{c}$ & $7.6 \pm 0.1 \mathrm{c}$ & $0.63 \pm 0.01 \mathrm{~b}$ & $2.89 \pm 0.02 \mathrm{~b}$ & $34.1 \pm 0.2 \mathrm{c}$ & $51.7 \pm 0.2 \mathrm{a}$ & $0.38 \pm 0.02 \mathrm{a}$ & $0.88 \pm 0.02 \mathrm{~b}$ & $0.38 \pm 0.02 \mathrm{a}$ & $0.21 \pm 0.01 \mathrm{~b}$ & $11.6 \pm 0.1 \mathrm{~b}$ & $35.9 \pm 0.2 \mathrm{c}$ & $52.5 \pm 0.2 \mathrm{a}$ & \\
\hline & $1 \mathrm{kGy}$ & $0.118 \pm 0.001 \mathrm{~b}$ & $7.8 \pm 0.1 \mathrm{~b}$ & $0.71 \pm 0.01 \mathrm{a}$ & $2.59 \pm 0.03 \mathrm{c}$ & $37.4 \pm 0.1 \mathrm{a}$ & $48.1 \pm 0.2 \mathrm{~b}$ & $0.30 \pm 0.01 \mathrm{~b}$ & $1.07 \pm 0.02 \mathrm{a}$ & $0.37 \pm 0.02 \mathrm{a}$ & $0.34 \pm 0.01 \mathrm{a}$ & $11.7 \pm 0.1 \mathrm{~b}$ & $39.5 \pm 0.1 \mathrm{a}$ & $48.8 \pm 0.2 \mathrm{c}$ & \\
\hline & $2 \mathrm{kGy}$ & $0.37 \pm 0.01 \mathrm{a}$ & $8.5 \pm 0.1 \mathrm{a}$ & $0.54 \pm 0.01 \mathrm{c}$ & $3.81 \pm 0.04 \mathrm{a}$ & $35.2 \pm 0.3 \mathrm{~b}$ & $48.3 \pm 0.4 \mathrm{~b}$ & $0.38 \pm 0.02 \mathrm{a}$ & $0.77 \pm 0.02 \mathrm{c}$ & $0.33 \pm 0.02 \mathrm{~b}$ & $0.21 \pm 0.03 \mathrm{~b}$ & $14.0 \pm 0.1 \mathrm{a}$ & $36.8 \pm 0.3 \mathrm{~b}$ & $49.1 \pm 0.4 \mathrm{~b}$ & \\
\hline Homoscedasticity $^{b}$ & $p$-value & $<0.001$ & 0.004 & 0.010 & 0.243 & 0.023 & 0.015 & 0.490 & 0.392 & 0.751 & 0.04 & 0.237 & 0.018 & 0.027 & \\
\hline \multirow[t]{3}{*}{ One-way ANOVA $^{c}$} & $p$-value & $<0.001$ & $<0.001$ & $<0.001$ & $<0.001$ & $<0.001$ & $<0.001$ & $<0.001$ & $<0.001$ & $<0.001$ & $<0.001$ & $<0.001$ & $<0.001$ & $<0.001$ & \\
\hline & & C6:0 & C16:0 & C16:1 & C18:0 & C18:1 & C18:2 & $\mathrm{C} 20: 0$ & $\mathrm{C} 20: 1$ & $\mathrm{C} 20: 2$ & $\mathrm{C} 22: 0$ & $\mathrm{C} 24: 0$ & SFA & MUFA & PUFA \\
\hline & 0 kGy & $0.11 \pm 0.01 \mathrm{c}$ & $13.1 \pm 0.1 \mathrm{c}$ & $0.24 \pm 0.01 \mathrm{c}$ & $2.24 \pm 0.03 \mathrm{c}$ & $37.2 \pm 0.3 \mathrm{~b}$ & $39.3 \pm 0.3 \mathrm{a}$ & $0.21 \pm 0.02 \mathrm{~b}$ & $5.7 \pm 0.1 \mathrm{a}$ & $0.33 \pm 0.01 \mathrm{a}$ & $0.20 \pm 0.01 \mathrm{~b}$ & $0.18 \pm 0.01 \mathrm{~b}$ & $16.6 \pm 0.1 \mathrm{c}$ & $43.2 \pm 0.2 \mathrm{~b}$ & $40.2 \pm 0.3 \mathrm{a}$ \\
\hline \multirow[t]{2}{*}{ Hydnum repandum } & $1 \mathrm{kGy}$ & $0.74 \pm 0.01 \mathrm{~b}$ & $16.4 \pm 0.1 \mathrm{~b}$ & $0.27 \pm 0.01 \mathrm{~b}$ & $2.8 \pm 0.1 \mathrm{~b}$ & $40.9 \pm 0.4 \mathrm{a}$ & $33.3 \pm 0.3 \mathrm{~b}$ & $0.26 \pm 0.01 \mathrm{a}$ & $2.9 \pm 0.1 \mathrm{~b}$ & $0.32 \pm 0.01 \mathrm{a}$ & $0.32 \pm 0.01 \mathrm{a}$ & $0.40 \pm 0.01 \mathrm{a}$ & $21.6 \pm 0.1 \mathrm{~b}$ & $44.2 \pm 0.3 \mathrm{a}$ & $34.1 \pm 0.3 \mathrm{~b}$ \\
\hline & $2 \mathrm{kGy}$ & $1.0 \pm 0.1 \mathrm{a}$ & $17 \pm 1 \mathrm{a}$ & $0.30 \pm 0.02 \mathrm{a}$ & $2.9 \pm 0.1 \mathrm{a}$ & $40 \pm 1 \mathrm{a}$ & $33 \pm 1 \mathrm{~b}$ & $0.26 \pm 0.02 \mathrm{a}$ & $2.5 \pm 0.1 \mathrm{c}$ & $0.28 \pm 0.03 \mathrm{~b}$ & $0.31 \pm 0.02 \mathrm{a}$ & $0.39 \pm 0.04 \mathrm{a}$ & $23 \pm 1 \mathrm{a}$ & $43 \pm 1 \mathrm{~b}$ & $34 \pm 1 \mathrm{~b}$ \\
\hline Homoscedasticity $^{b}$ & $p$-value & $<0.001$ & $<0.001$ & 0.127 & 0.029 & 0.007 & 0.092 & 0.291 & 0.082 & 0.015 & 0.028 & $<0.001$ & $<0.001$ & 0.001 & 0.087 \\
\hline One-way ANOVA $^{c}$ & $p$-value & $<0.001$ & $<0.001$ & $<0.001$ & $<0.001$ & $<0.001$ & $<0.001$ & $<0.001$ & $<0.001$ & $<0.001$ & $<0.001$ & $<0.001$ & $<0.001$ & $<0.001$ & $<0.001$ \\
\hline
\end{tabular}

dw- dry weight.

${ }^{a}$ Different letters in each column and for each mushroom indicate significant differences among mean values of each gamma irradiation level.

${ }^{b}$ Homoscedasticity among irradiation doses was tested by means of the Levene test: homoscedasticity, $p$-value $>0.05$; heteroscedasticity, $p$-value $<0.05$.

${ }^{c} p<0.05$ meaning that the mean value of the evaluated parameter of at least one irradiation differs from the others (in this case multiple comparison tests were performed). 
Table 5. Organic acids composition of $B$. edulis and H. repandum samples submitted to different gamma irradiation doses. The results are presented as mean $\pm \mathrm{SD}^{a}$.

\begin{tabular}{llccccc}
\hline & & $\begin{array}{c}\text { Oxalic acid } \\
(\mathrm{g} / 100 \mathrm{~g} \mathrm{dw})\end{array}$ & $\begin{array}{c}\text { Malic acid } \\
(\mathrm{g} / 100 \mathrm{~g} \mathrm{dw})\end{array}$ & $\begin{array}{c}\text { Citric acid } \\
(\mathrm{g} / 100 \mathrm{~g} \mathrm{dw})\end{array}$ & $\begin{array}{c}\text { Fumaric acid } \\
(\mathrm{g} / 100 \mathrm{~g} \mathrm{dw})\end{array}$ & $\begin{array}{c}\text { Total organic acids } \\
(\mathrm{g} / 100 \mathrm{~g} \mathrm{dw})\end{array}$ \\
\hline \multirow{3}{*}{ Boletus edulis } & $0 \mathrm{kGy}$ & $0.485 \pm 0.004 \mathrm{a}$ & $\mathrm{nd}$ & $4.7 \pm 0.1 \mathrm{~b}$ & $0.067 \pm 0.001 \mathrm{~b}$ & $5.3 \pm 0.1 \mathrm{~b}$ \\
& $1 \mathrm{kGy}$ & $0.36 \pm 0.01 \mathrm{~b}$ & $\mathrm{nd}$ & $5.3 \pm 0.1 \mathrm{a}$ & $0.082 \pm 0.002 \mathrm{a}$ & $5.71 \pm 0.05 \mathrm{a}$ \\
& $2 \mathrm{kGy}$ & $0.18 \pm 0.1 \mathrm{c}$ & $\mathrm{nd}$ & $4.0 \pm 0.1 \mathrm{c}$ & $0.069 \pm 0.004 \mathrm{~b}$ & $4.3 \pm 0.1 \mathrm{c}$ \\
\hline Homoscedasticity $^{b}$ & $p$-value & 0.002 & - & 0.283 & 0.034 & 0.302 \\
One-way ANOVA $^{c}$ & $p$-value & $<0.001$ & - & $<0.001$ & $<0.001$ & $<0.001$ \\
\hline \multirow{3}{*}{ Hydnum repandum } & $0 \mathrm{kGy}$ & $0.0031 \pm 0.0002 \mathrm{c}$ & $3.47 \pm 0.03 \mathrm{~b}$ & $3.82 \pm 0.03 \mathrm{~b}$ & $0.61 \pm 0.01 \mathrm{~b}$ & $7.90 \pm 0.04 \mathrm{~b}$ \\
& $1 \mathrm{kGy}$ & $0.030 \pm 0.002 \mathrm{a}$ & $3.28 \pm 0.04 \mathrm{~b}$ & $4.02 \pm 0.05 \mathrm{a}$ & $0.63 \pm 0.01 \mathrm{ab}$ & $7.96 \pm 0.05 \mathrm{~b}$ \\
\hline Homoscedasticity $^{b}$ & $2 \mathrm{kGy}$ & $0.027 \pm 0.002 \mathrm{~b}$ & $5.6 \pm 0.4 \mathrm{a}$ & $3.9 \pm 0.2 \mathrm{ab}$ & $0.65 \pm 0.04 \mathrm{a}$ & $10.2 \pm 0.4 \mathrm{a}$ \\
One-way ANOVA $^{c}$ & $p$-value & $<0.001$ & $<0.001$ & $<0.001$ & $<0.001$ & $<0.001$ \\
\hline
\end{tabular}

dw- dry weight; nd- not detected.

${ }^{a}$ Different letters in each column and for each mushroom indicate significant differences among mean values of each gamma irradiation level.

${ }^{b}$ Homoscedasticity among irradiation doses was tested by means of the Levene test: homoscedasticity, $P$-value $>0.05$; heteroscedasticity, $P$-value $<0.05$.

${ }^{c} p<0.05$ meaning that the mean value of the evaluated parameter of at least one irradiation differs from the others (in this case multiple comparison tests were performed). 
Table 6. In vitro antioxidant properties obtained for the extracts B. edulis and H. repandum samples submitted to different gamma irradiation doses $(\mathrm{mean} \pm \mathrm{SD})^{a}$. Values are presented as $\mathrm{EC}_{50}$ values $(\mathrm{mg} / \mathrm{mL})$ for all assays except Folin-Ciocalteau, expressed as mg GAE/g extract.

\begin{tabular}{|c|c|c|c|c|c|c|}
\hline & & & Reducing & power & Lipid peroxidat & on inhibition \\
\hline & & DPPH scavenging & Ferricyanide/Prussian & Folin-Ciocalteu & $\beta$-Carotene bleaching & TBARS formation \\
\hline & & activity & blue assay & assay & inhibition & inhibition \\
\hline & $0 \mathrm{kGy}$ & $1.54 \pm 0.03 \mathrm{c}$ & $0.71 \pm 0.01 \mathrm{c}$ & $37 \pm 1 \mathrm{a}$ & $1.6 \pm 0.1 \mathrm{c}$ & $1.6 \pm 0.1 \mathrm{a}$ \\
\hline Boletus edulis & 1 kGy & $2.22 \pm 0.03 \mathrm{a}$ & $0.96 \pm 0.02 \mathrm{a}$ & $30 \pm 1 \mathrm{~b}$ & $2.5 \pm 0.3 \mathrm{a}$ & $0.53 \pm 0.03 \mathrm{~b}$ \\
\hline & 2 kGy & $1.9 \pm 0.1 \mathrm{~b}$ & $0.76 \pm 0.02 \mathrm{~b}$ & $36 \pm 1 \mathrm{a}$ & $1.9 \pm 0.2 \mathrm{~b}$ & $0.54 \pm 0.02 \mathrm{~b}$ \\
\hline Homoscedasticity $^{b}$ & $p$-value & 0.001 & $<0.001$ & 0.018 & $<0.001$ & $<0.001$ \\
\hline One-way ANOVA ${ }^{c}$ & $p$-value & $<0.001$ & $<0.001$ & $<0.001$ & $<0.001$ & $<0.001$ \\
\hline & 0 kGy & $31 \pm 1 \mathrm{c}$ & $2.47 \pm 0.05 \mathrm{c}$ & $6.8 \pm 0.2 \mathrm{~b}$ & $3.8 \pm 0.1 \mathrm{~b}$ & $0.9 \pm 0.1 \mathrm{~b}$ \\
\hline Hydnum repandum & $1 \mathrm{kGy}$ & $34 \pm 1 \mathrm{~b}$ & $2.6 \pm 0.1 \mathrm{~b}$ & $7.6 \pm 0.1 \mathrm{a}$ & $3.0 \pm 0.4 \mathrm{c}$ & $0.7 \pm 0.1 \mathrm{c}$ \\
\hline & $2 \mathrm{kGy}$ & $39.6 \pm 0.5 \mathrm{a}$ & $2.8 \pm 0.1 \mathrm{a}$ & $6.9 \pm 0.2 \mathrm{~b}$ & $8.3 \pm 0.4 \mathrm{a}$ & $1.1 \pm 0.1 \mathrm{a}$ \\
\hline Homoscedasticity $^{b}$ & $p$-value & 0.022 & 0.051 & 0.069 & 0.197 & 0.002 \\
\hline One-way ANOVA ${ }^{c}$ & $p$-value & $<0.001$ & $<0.001$ & $<0.001$ & $<0.001$ & $<0.001$ \\
\hline
\end{tabular}

dw- dry weight.

${ }^{a}$ Different letters in each column and for each mushroom indicate significant differences among mean values of each gamma irradiation level.

${ }^{b}$ Homoscedasticity among irradiation doses was tested by means of the Levene test: homoscedasticity, $P$-value $>0.05$; heteroscedasticity, $P$-value $<0.05$.

${ }^{c} p<0.05$ meaning that the mean value of the evaluated parameter of at least one irradiation differs from the others (in this case multiple comparison tests were performed).

$\mathrm{EC}_{50^{-}}$extract concentration corresponding to $50 \%$ of antioxidant activity or 0.5 of absorbance for the Ferricyanide/Prussian blue assay. Concerning the Folin-Ciocalteu assay, higher values mean higher reducing power; for the other assays, the results are presented in $\mathrm{EC}_{50}$ values, what means that higher values correspond to lower reducing power or antioxidant potential. 
Figure 1. Biplot of objects (irradiation doses) and component loadings (evaluated parameters) for B. edulis.

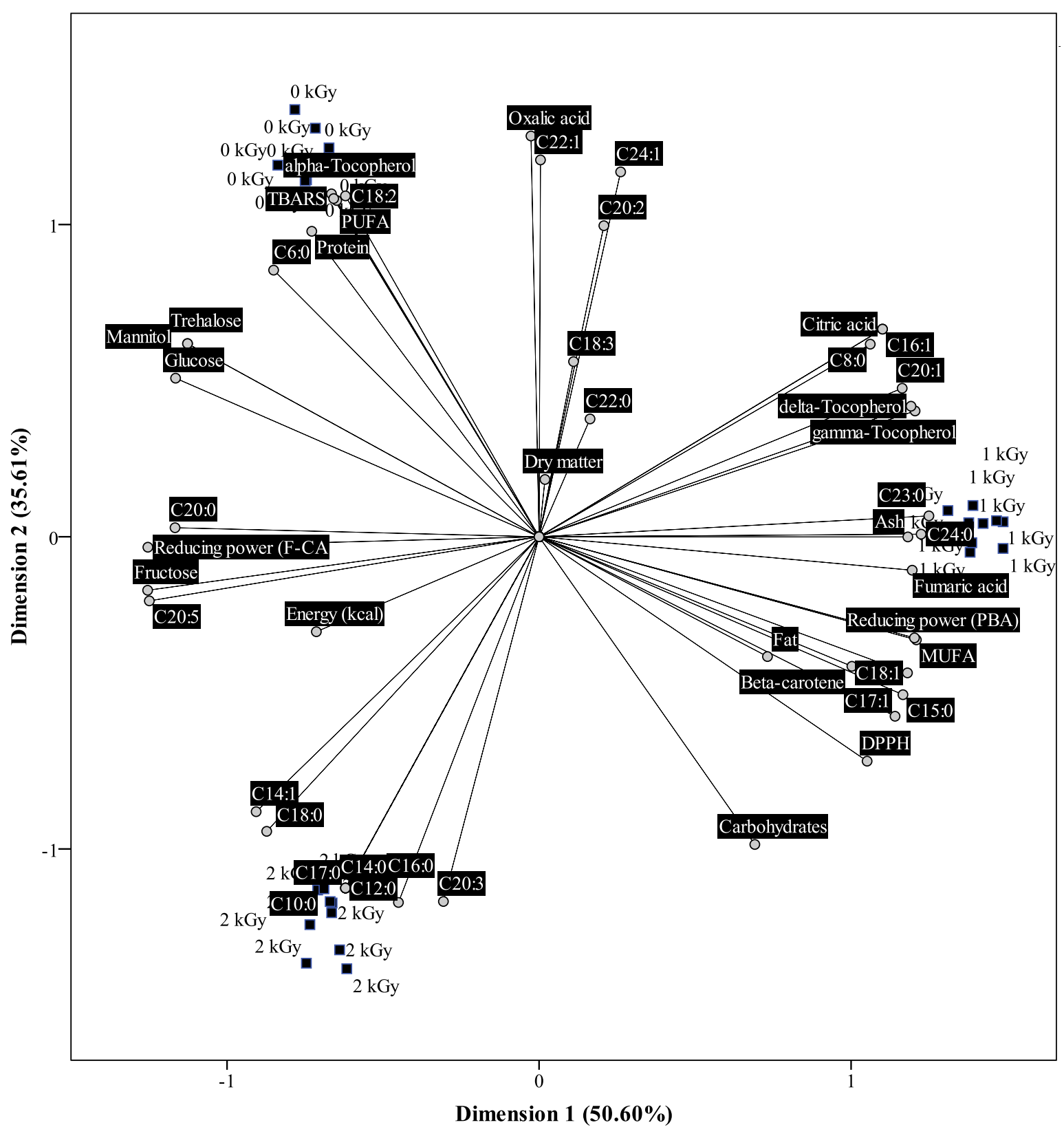


Figure 2. Biplot of objects (irradiation doses) and component loadings (evaluated parameters) for H. repandum.

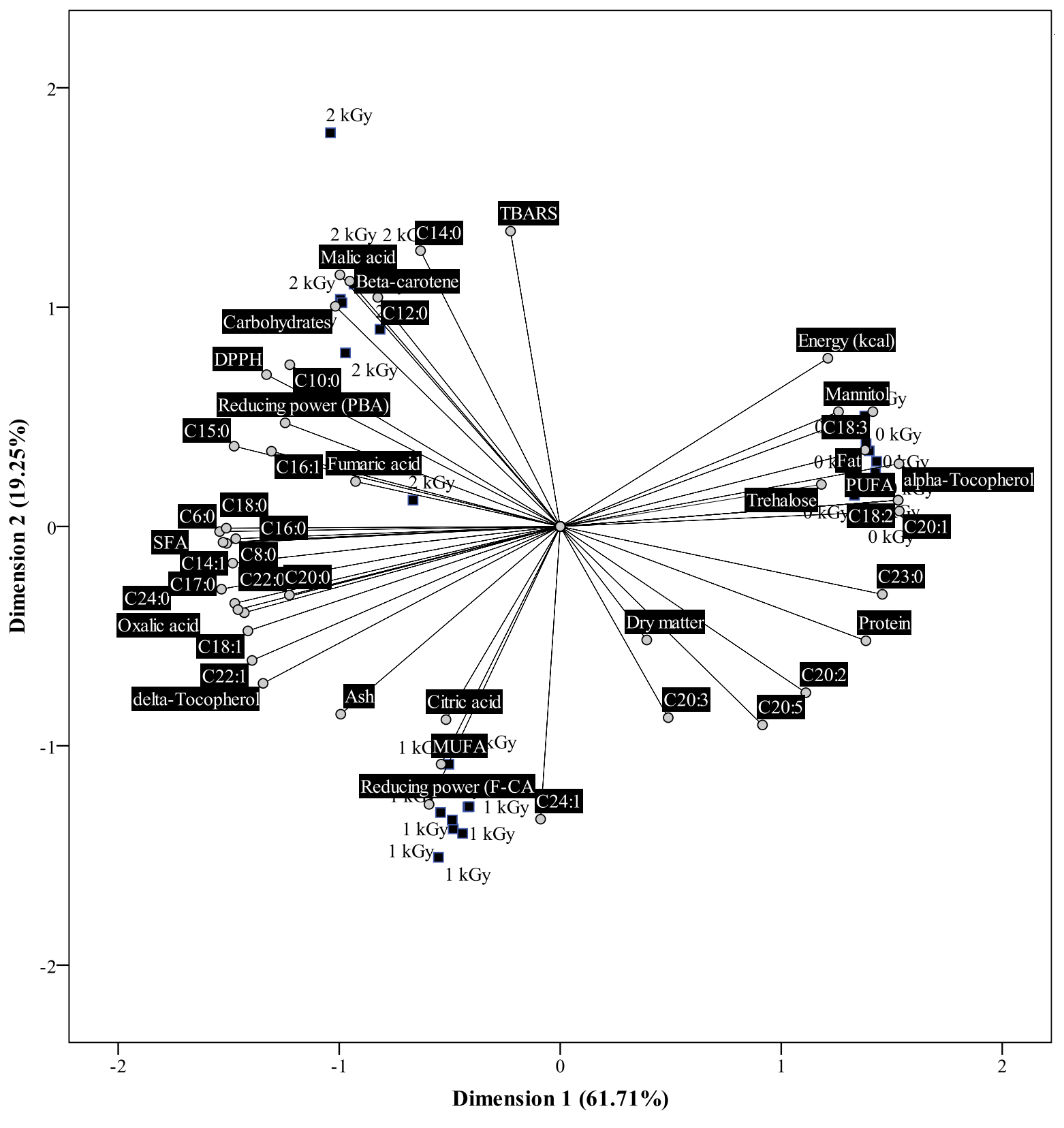

